\title{
Corrigendum: Neurodegeneration and microtubule dynamics: death by a thousand cuts
}

\author{
Jyoti Dubey ${ }^{1,2,3 \dagger}$, Neena Ratnakaran ${ }^{1 \dagger}$ and Sandhya P. Koushika ${ }^{1 *}$ \\ ${ }^{1}$ Department of Biological Sciences, Tata Institute of Fundamental Research, Mumbai, India, ${ }^{2}$ Institute for Stem Cell Biology \\ and Regenerative Medicine, Bangalore, India, ${ }^{3}$ Manipal University, Manipal, India
}

Keywords: Microtuble stability, Alzheimer's disease, Parkinson Disease, dying back, hyperstable microtubules, microtubule signaling hubs

\section{A corrigendum on}

OPEN ACCESS

Edited and reviewed by: Yogesh P. Wairkar, University of Texas Medical Branch,

*Correspondence:

Sandhya P. Koushika spkoushika@tiff.res.in

${ }^{\dagger}$ These authors have contributed equally to this work.

Received: 21 January 2016 Accepted: 25 January 2016 Published: 09 February 2016

Citation:

Dubey J, Ratnakaran N and Koushika SP (2016) Corrigendum: Neurodegeneration and microtubule dynamics: death by a thousand cuts.

Front. Cell. Neurosci. 10:26. doi: 10.3389/fncel.2016.00026
Neurodegeneration and microtubule dynamics: death by a thousand cuts by Dubey, J., Ratnakaran, N., and Koushika, S. P. (2015). Front. Cell. Neurosci. 9:343. doi: 10.3389/fncel.2015.00343

In the original manuscript, an affiliation for Jyoti Dubey as Manipal University was missing. In addition we would prefer to write expanded name of InStem as Institute for Stem Cell Biology and Regenerative Medicine. This correction does not affect scientific integrity of the review.

\section{AUTHOR CONTRIBUTIONS}

All authors listed, have made substantial, direct and intellectual contribution to the work, and approved it for publication.

Conflict of Interest Statement: The authors declare that the research was conducted in the absence of any commercial or financial relationships that could be construed as a potential conflict of interest.

Copyright (c) 2016 Dubey, Ratnakaran and Koushika. This is an open-access article distributed under the terms of the Creative Commons Attribution License (CC BY). The use, distribution or reproduction in other forums is permitted, provided the original author(s) or licensor are credited and that the original publication in this journal is cited, in accordance with accepted academic practice. No use, distribution or reproduction is permitted which does not comply with these terms. 